\title{
Distributing the Wealth from the Earth
}

\author{
Javier Arellano Yanguas and Andrés Mejía Acosta
}

\begin{abstract}
This article explains different criteria and mechanisms for distributing extractive industries (El) revenues between central and local governments across countries and territories. It reveals that institutional or systemic predictors of distribution are not enough to explain different shares of revenue sharing. The proportion of El revenues effectively transferred to sub-national governments is neither related to the level of fiscal decentralisation of the countries nor to their federal or unitary nature. We suggest that the relative strength of the sub-national governments vis-à-vis the central government as well as the relative alignment of preferences between local and national governments have a significant impact on transferring $\mathrm{El}$ revenues. We conclude that administrative or fiscal decentralisation alone are not sufficient to ensure an effective distribution of natural resource revenues. Effective political decentralisation can reduce vertical asymmetries and ensure a more equitable distribution of wealth across all jurisdictions.
\end{abstract}

\section{Introduction}

The recent price and investment boom in the mining and hydrocarbon sectors has triggered widespread expectations for greater economic and social development, especially among developing countries. The potential success of a development strategy based on the extraction of non-renewable resources is largely dependent on the share of revenue captured by the state from the extractive sector, and the methods that governments adopt to use and distribute that revenue (Bebbington 2012). This article acknowledges existing dilemmas around the extraction of revenue - through taxes and royalties - but focuses on the criteria used to allocate revenue from extractive industries (EI) to different levels of government.

The choice of a mechanism to allocate EI revenue is an inherently political process. The exploitation of natural resources has some specific features that tend to differentiate the criteria used to distribute this revenue from the general decentralising framework in each country. In the first place, minerals, oil and gas are frequently concentrated in specific territories; the people living there are likely to demand a share of the proceeds from the extraction to compensate for the use of their resources and the negative externalities associated with extraction. Secondly, minerals and hydrocarbons are non-renewable, which puts additional pressure on replacing the extracted resources with some investment in durable assets, giving tangible (e.g. physical infrastructure) or intangible (e.g. education) benefits. These features have led to greater decentralisation of EI-related revenue in recent years, but the methods and mechanisms adopted vary widely across countries. We find that distributive mechanisms do not necessarily follow existing lines of administrative or fiscal decentralisation but rather, are renegotiated across existing political motivations and organisational capacity of the main stakeholders.

This article explores three questions:

- How do central governments share (or distribute) the revenue from extractive industries with different levels of sub-national government (vertical distribution)?

- How do governments distribute EI revenue across similar jurisdictions, some of which are extractive but others not (horizontal distribution)?

- To which extent do factors such as the structure of the state and other conventional political features determine the degree of 
decentralisation of EI revenues and the modality of distribution?

In this article we contend that variations in the horizontal and vertical distribution of revenues does not only depend on technical considerations for optimal distribution but also on the political motivations and coalitions to distribute EI revenues. We highlight the relative importance of the timing of reforms to the EI sector, the importance of federal versus unitary states, and the relative bargaining power and alignment of sub-national actors vis-à-vis the central government. We discuss some preliminary explanations and draw some policy implications.

The article proceeds as follows: Section 2 reviews the main features of existing methods, rules and practices for allocating resource revenues at subnational level. Section 3 shows the variation in ten countries worldwide for which we have identified reliable and comparable data on the distribution of revenue. Finally, Section 4 discusses some of the salient political factors that influence the adoption of different revenue allocation policies. It also summarises the key arguments and identifies knowledge gaps to better understand the linkage between allocation formulas and development outcomes at the local level.

\section{Methods for the distribution of resource revenue}

This section gives an overview of common criteria used to distribute EI-related revenue from central to sub-national governments (vertical distribution), as well as commonly used methods to determine the distribution across sub-national governments (horizontal distribution).

\subsection{Vertical distribution of El revenues}

The key policy challenge for an effective vertical distribution of revenues is to balance the need to minimise fiscal volatility and financial liabilities while appeasing increased social demands coming from sub-national governments. In short, EI revenues ignite the fiscal tensions between central, regional and local governments. Three criteria are commonly taken into consideration when deciding the distribution of EI revenues (Ahmad and Singh 2003): (a) matching (administrative) responsibilities to the level of fiscal transfers; (b) ensuring a political equilibrium between the centre and the periphery; and (c) managing volatile revenues.

\section{a Matching responsibilities}

According to this criterion, the share of transfers (including EI-related transfers, all other fiscal transfers and locally raised taxes) should match the revenue needed by sub-national governments to fund the public services they are responsible for (Schoeder and Smoke 2002). In practice, evaluating the 'appropriate' level of public services as well as the 'matching revenue' needed to fund them are difficult to assess and forecast; extractive territories may claim a greater entitlement to benefiting from EI-related revenues but the actual allocations are subject to political interpretation and intense bargaining.

\section{b Political equilibrium between centre and periphery}

In the context of good governance reforms favouring decentralisation, the presence of the extractive sector has encouraged demands from sub-national governments to manage part of the proceeds from EI. Frequently this has been formulated as a 'right' that has been enshrined in the constitutions of the countries (Ahmad and Mottu 2003; Ross 2007). The literature suggests that pre-existing levels of fiscal and political decentralisation would further strengthen the role of opposition parties and sub-national actors to demand greater decentralisation reforms, but conversely, when central governments have contained or delayed pressures for fiscal or political decentralisation, the overall level of decentralisation tends to remain weak (Falleti 2010).

\section{c Managing volatile revenues}

Given the unpredictable nature of commodity prices, revenue from extractive industries has the potential to induce fiscal volatility in national and sub-national public finances (Ahmad and Singh 2003). To minimise the impact of revenue volatility, some have advocated a centralised management of EI revenue through a savings or stabilisation fund (Ahmad and Mottu 2003). This is done partly to accumulate savings at the central level, but also to protect sub-national entities from the problems arising from handling revenue windfalls. If fiscal centralisation is not technically feasible or politically desirable, it is recommended to devolve more 'stable' revenue that is independent from international prices - such as royalties (when these are calculated based on gross production), licences and other fees. Finally, if volatile tax revenue is to be decentralised, mechanisms should be introduced to stabilise the flow of resources (Davis et al. 2003). 
Each of these criteria reveal the unavoidable political nature of distributive debates and its consequences. The actual allocations show the tensions between objectively defined needs and local perceptions, between the national perspective and the demands of producing regions, between the moderation of technical proposals and the urge from radical decentralisation that frequently accompany the discovery of mineral riches, between ideal political designs and the influence of pre-existing decentralisation arrangements.

Section 2.2 discusses additional allocation criteria for distributing rents across producing and non-producing districts.

\subsection{Horizontal distribution of revenue from EI}

A key discussion around the allocation of EI revenue across different sub-national jurisdictions focuses on whether to redistribute revenue solely to territories that host extractive activities, and whether the central government should reallocate revenue through discretionary or institutionalised rules, such as the adoption of a proportionality formula. The existing literature has identified three types of mechanisms: (a) direct allocation from the central government, (b) formula-based participation, and (c) devolution. In practice, countries combine two or more criteria when adopting redistribution formulas.

\section{a Allocation from the central government}

In this scenario, central governments seek to centralise the macroeconomic management of revenue to minimise the risk of uncontrolled sub-national expenditure. Government finance is usually transferred on an annual basis for specific projects and development or regional investment funds. Governments could also distribute available revenue through competitive investment grants aimed at supporting specific types of projects. In principle, the adoption of competitive grant mechanisms by the central government has the potential to reinforce pre-existing economic inequalities and power asymmetries between sub-national governments. Some territories with solid public finances may have greater expenditure capabilities or possess the technical ability to formulate and obtain additional resources through competitive grant schemes. In any case, these mechanisms of competitive allocation offer more transparent alternatives than allocating valuable resources through protracted or clandestine political negotiations which may intensify existing political divides.

\section{b Formula-based participation}

Through this mechanism, sub-national governments receive a pre-determined share of the revenue raised nationally. A formula set by law determines both the amount to be allocated and the obligation of the central government to transfer those resources to both producing and non-producing territories. The different needs and characteristics of each jurisdiction can be factored into the formula to compensate for preexisting inequalities, the size of the population and, in some cases, the tax gap. The allocation formula can also reflect different variables on government performance, such as the fiscal effort of each territorial unit.

While formulas can become more complex to reflect different dynamics, the ultimate challenge for policymakers is to ensure fairness and efficiency. Excessive complexity can trigger conflicts regarding interpretation of the formula, counteracting any marginal gain in terms of equity and efficiency. However, formula-based participation, even if well designed, can also have some drawbacks. It reduces the flexibility of the central government to manage the macroeconomic challenges associated with EIs, and does not take into consideration the geographical source of tax revenue.

\section{c Devolution}

Devolution involves the transfer of revenue, or a proportion of it, to the jurisdiction where the income has been generated. ${ }^{1}$ In the case of revenue from EI, devolution makes the producing regions, and sometimes those that host some infrastructure for exploitation (mainly ports), the only recipients of transfers. This mechanism aims to compensate producing regions for negative externalities linked to extraction, and the need to adjust infrastructure and public services to the presence of mining and oil operations (Brosio 2003). However, the concentration of transfers to producing regions might generate three types of problems:

(a) inequality between producing and nonproducing regions; (b) problems of revenue volatility in producing regions; and (c) to discourage collection of local taxes and distort the allocation of resources at the local level because of the abundance of transfers.

The implementation of devolution mechanisms requires identification of the jurisdictions that 
should be prioritised. The following two criteria are the most frequently used: (a) the geographical origin of the revenue, and (b) territories affected by negative externalities linked to extraction. ${ }^{2}$ The criterion of origin tries to compensate for the loss of natural capital (the mineral) by financial transfers to the governments of the territories where the extraction takes place. Such transfers should in principle help to develop other types of capital (human, physical, etc.) to enhance the developmental potential of those territories. Frequently, the strict application of this criterion leaves out neighbouring jurisdictions that are also affected by extraction. The criterion of negative externalities tries to solve this limitation. It takes into account environmental damage, but also the need to improve physical infrastructure (roads, the electrical grid, etc.) and to scale up public services in order to respond to the likely increase in population due to immigration from other regions of the country.

This section discussed the extent to which political or technical criteria largely informs the distribution of EI revenues. The next section looks at comparative data from a set of ten resource-rich countries to determine, for example, whether countries with greater fiscal and administrative decentralisation are in fact more likely to distribute a larger share of EI revenues to sub-national governments than formal unitary countries.

\section{Sub-national transfers in comparative perspective}

A brief review of the comparative evidence available (see Table 1 in Annex) shows that existing methods for distributing EI revenues between central and sub-national governments (vertical distribution), and across producing and non-producing regions (horizontal distribution) vary widely. The data, collected for ten resourcerich countries (oil and mining) where reliable and comparable information was located (Bolivia, Brazil, Colombia, Ecuador, Ghana, Indonesia, Mexico, Nigeria, Papua New Guinea and Peru) shows that allocations do not reflect the 'pure types' identified in the literature. Table 1 summarises the distribution of EI revenues between central, regional, state and local government levels according to the last reform in each country. ${ }^{3}$ This section highlights some patterns and regularities found in the distribution.

\subsection{Vertical distribution}

Table 1 reports countries according to their degree of decentralisation of EI revenues. Decentralisation is (a) low if all sub-national governments receive less than 10 per cent of state EI revenue (Ecuador, Ghana and Papua New Guinea); (b) medium if sub-national governments receive between 10 per cent and 50 per cent of the EI revenue (Colombia, Indonesia and Mexico); and (c) high if subnational governments receive more than 50 per cent of the EI revenue accrued to the central government (Bolivia, Brazil, Peru and Nigeria). The table also provides information on the share of total EI revenue that is formally allocated to each tier of government.

The first striking feature is that decentralisation of EI revenue is neither directly related to the formal territorial structure nor to the general level of decentralisation of the country. While there are federal countries like Brazil or Nigeria that effectively share a high proportion of EI revenues with regions, federal Mexico transfers less than 20 per cent of EI revenue. Conversely, some unitary countries such as Bolivia or Peru redistribute up to 55 per cent of their EI revenue to sub-national units. There is no clear association between the allocation of EI revenues and the share of fiscal decentralisation in each country either. Figure 1 shows that sub-national public expenditure as a share of total public expenditure is not associated with the decentralisation of EI revenues in six Latin American countries. Even though Peru and Ecuador have relatively low levels of fiscal decentralisation, the Peruvian state is highly decentralised when it comes to allocating EI revenues. A similar comparison happens between Brazil and Mexico, with Mexico favouring lower decentralisation of EI revenues despite having higher levels of fiscal decentralisation.

A second feature of vertical distribution is that sub-national beneficiaries (regional, state and local-level governments) vary widely as well. In federal states like Brazil, Nigeria and even Mexico, the bulk of allocated transfers go to state-level governments, probably because the central government spending is channelled through the existing fiscal decentralisation structure. In two of the three cases, we observe that revenues transferred to regional or statelevel governments more than double the share of 


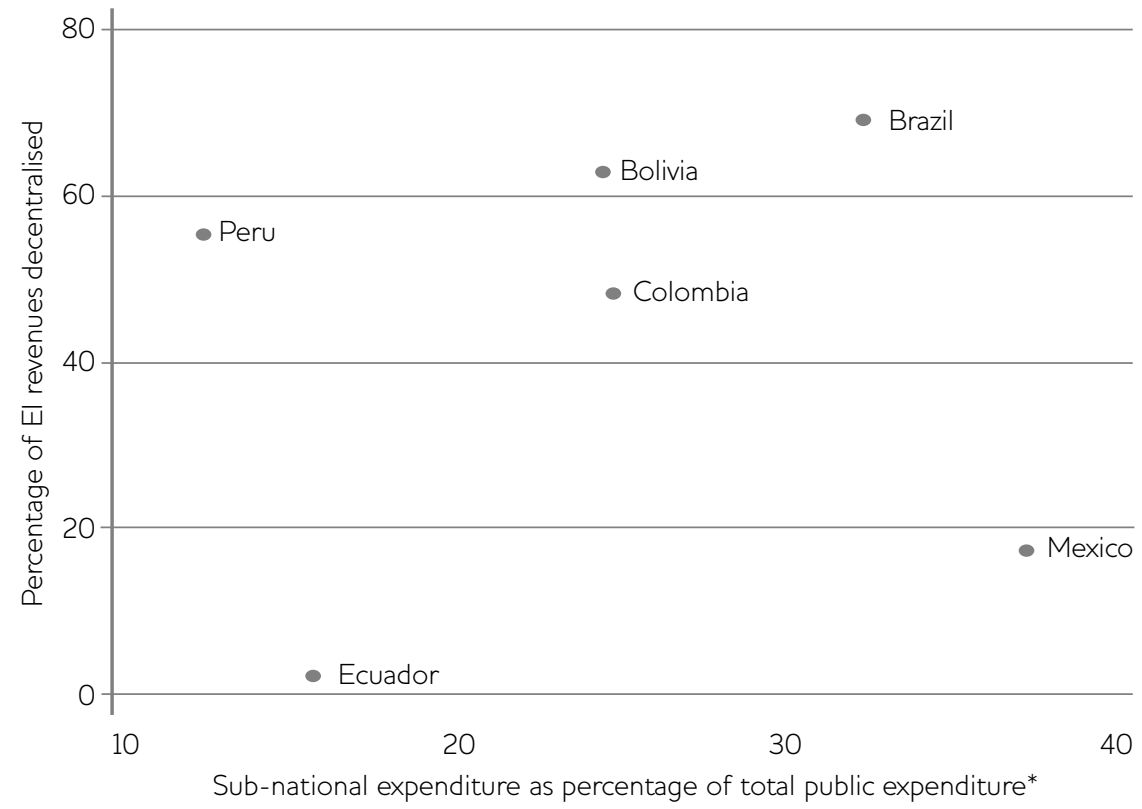

Note *Average for years 2000-07.

Source Data taken from Ruiz Duran (2011).

revenues allocated to local or municipal governments (45 per cent to 21 per cent in Brazil and 36 per cent to 18 per cent in Nigeria).

By contrast, in non-federal (or unitary) systems like Peru and Indonesia where decentralisation is a relatively new phenomena, local-level governments receive more than three times the share of EI revenues than state-level counterparts (43 per cent for municipalities compared to 12 per cent for regions in Peru, and 12 per cent compared to 3 per cent in Indonesia). Bolivia initially had a more equitable distribution across the three tiers of government (37 per cent to the national government, 37 per cent to the regional government and 26 per cent to municipalities). After 2012, President Morales increased fiscal transfers in favour of local governments (in the form of cash transfer schemes managed by the central government) while reducing transfers to regions (prefecturas), most of which were governed by opposition parties. These changes confirm the political nature of decentralising EI revenues: '[I]f confronted with the opportunity of need to decentralise, the national executive prefers to do it toward the local level, since mayors pose less of an electoral and financial threat than governors' (Falleti 2010).

\subsection{Horizontal distribution}

Table 1 also shows significant variation in the existing methods for distributing EI revenue to producing districts only or favouring a more equitable distribution across all territories including non-producing areas (horizontal distribution). Once again, the degree of decentralisation of EI revenues is not related to the type of beneficiaries. At high levels of decentralisation, countries like Bolivia would prioritise transfers to producing districts and allow some distribution to non-producing regions, whereas Nigeria would favour formulabased participation to benefit all sub-national governments and restrict the funds going to producing states only (Kâ Diongue, Giraud and Renouard 2011). In contrast, Brazil and Peru have preferred formulas that devolve revenue back to the producing region or state and localities in producing regions. Yet the Brazilian government has sought to compensate nonproducing regions by investing in essential infrastructure (ports, roads, pipelines and railways) to support extractive activities. Furthermore, the Brazilian Congress adopted new legislation in 2013 to redistribute oil revenue among all federal states, and is currently in the process of approving a law that allows the use of oil-related revenue in education 
sector expenditure. However, the three producing states (and original beneficiaries of the devolution mechanism) have stopped the law's implementation through an appeal to the Constitutional Court (Fick 2013; Reuters 2013).

In countries with a medium level of decentralisation of EI revenue, revenue tends to be distributed through a combination of devolution and formula-based mechanisms. Colombia has moved in a similar direction as Brazil - from a system that concentrated transfer of royalties on the producing regions, to a more equitable system where most of the royalties are distributed between all sub-national jurisdictions. In Indonesia, oil-related transfers go exclusively to the producing areas (provinces and districts), but 50 per cent of the value of these transfers is discounted from the ordinary transfers that these provinces and districts should receive from the national government (Morgandi 2008). More recently, a percentage of the EI revenue has been given to jurisdictions adjacent to the producing ones to compensate negative externalities linked to extraction. However, these criteria frequently generate grievances because negative externalities do not coincide with the boundaries of official jurisdictions. This opens the way for continuous demands from populations who feel excluded from fiscal distribution. Mexico is the only country to distribute EI revenue proportionally across the entire country through an allocation formula.

In countries with low levels of EI decentralisation (Ecuador, Ghana and Papua New Guinea), most EI transfers tend to favour producing regions only. In Ecuador, sub-national governments (provinces and municipalities) have benefited from fiscal decentralisation since the mid-1990s, but this devolution did not include the specific transfer of EI revenues. With the advent of the commodities boom after 2004, the government further centralised the allocation of EI revenues while reducing the fiscal and political leverage of the producing regions as well.

The review of the different criteria followed by the countries in our sample provides some preliminary evidence that needs to be further tested. The data reported in Figure 1 confirms that the general degree of fiscal decentralisation of the country matters. Countries with higher levels of decentralisation (Brazil and Mexico) tend to prioritise a type of redistribution that benefits all the regions across the country. At the opposite extreme, countries with a weak decentralisation (Peru and Ecuador) concentrate the transfers on the producing jurisdictions. Colombia and Bolivia, which have moderate levels of fiscal decentralisation, combine devolution to the producing regions with formula-based distribution to all the territories. The argument holds, in general terms, for the four non-Latin American countries included in our sample. The evidence also suggests that high levels of fiscal decentralisation provide subnational governments across the country with greater bargaining power to demand the distribution of EI revenues more broadly.

\section{Discussion and some implications for policy reforms}

This article has offered a brief overview of existing mechanisms for distributing EI revenues and the empirical variation of mechanisms across cases and territories. The review illustrates how little is known about the institutions and political dynamics of transferring EI revenues from central to subnational governments. There are several questions that need to be addressed before making recommendations to citizens, national policymakers and international donors about the 'optimal' distribution mechanisms. In this section, we discuss these challenges, interpret the available evidence and discuss alternative approaches to understand how to maximise the impact of EI revenues at the sub-national level.

\subsection{Who benefits from El revenues?}

We find significant variation regarding the beneficiaries of natural resource revenues, particularly depending on whether these revenues benefit producing regions and localities alone or whether they are further distributed to benefit non-producing jurisdictions as well.

a We do not find a consistent pattern to distributing EI revenues to solely target producing districts or more equitably across all districts. The federal estates in the sample (Nigeria, Brazil and Mexico) tend to favour a more equitable distribution than non-federal countries. Governments in unitary settings have sought to re-centralise the management of EI revenues in order to ensure a more equitable distribution of EI revenues. In cases like Ecuador, 
Colombia and federal Brazil, the government has invested considerable resources to develop a national infrastructure, which benefits both producing and non-producing regions.

However, we have suggested that greater centralisation of EI revenues in non-federal countries may allow the executive considerable discretionality to benefit partisan allies or undermine the opposition in producing and non-producing regions.

b One possibility to be further explored is that countries will favour more equitable distribution of EI revenues when sub-national governments also take part (directly or indirectly) in the national governing coalition. In principle, if local elites have strong connections with central governments, they may be more able to gain access to fiscal resources, projects, discretionary transfers and policy influence. This is the case of Bolivia and Colombia. In Bolivia, President Evo Morales would have preferred to re-centralise revenues after the 2005 reforms but had to compromise a fairer and more proportional distribution of revenues with the opposition governors and mayors (especially in three hydrocarbon-rich regions).

c However, a stronger alignment between central and sub-national governments may also mean greater dependency on the executive and less autonomy to pursue the regions' own development strategies.

\subsection{Fiscal decentralisation and extractive revenues}

Much of the debate around the allocation of EI revenues fails to take into account the relative weight of the extractives sector in the overall fiscal decentralisation and budgetary management. An initial comparison suggests that there is no relation between the share of EI revenues and the share of government revenues (as percentage of GDP) transferred from central to sub-national governments. In some countries like Ecuador or Mexico, the share of fiscal transfers tends to be greater than the share of EI transfers, whereas in Bolivia, Peru, Brazil or Colombia, it is the opposite, there is greater decentralisation of EI revenues.

a One potential explanation is the timing of reforms: if fiscal reforms precede the distribution of EI revenues, the share of sub- national government spending appears to be higher than the share of EI transfers, other things being equal. This is the case in Ecuador, which adopted fiscal decentralisation in 1997 long after the devolution of EI revenues. Conversely, EI transfers are likely to be higher in a context of fiscal decentralisation if they were bargained during a commodities boom as in the case of Brazil, Peru and Bolivia. In cases like Peru and Bolivia, redistribution reforms adopted after 2000 took place in the context of strengthening democratisation and fiscal decentralisation reforms, which reinforced the strength of local actors to organise electorally, promote social mobilisations and disrupt the workings of extractive activities (Arellano Yanguas 2012; Crabtree and Chaplin 2013).

b Governments may also be more reluctant to share extractive revenues when these represent a significant part of total government spending. In practice, there are multiple ways in which EI revenues could be managed by the central government to fund capital or current investments without channelling through fiscal decentralisation formulas. Ecuador, Colombia and to a lesser extent Bolivia are cases where central governments have recentralised the distribution of EI revenues while gaining greater political leverage over the management of these allocations.

c It remains an empirical question as to the extent to which greater recentralisation of EI revenues in the hands of the executive may offer greater opportunities for discretionary use of EI revenues in the form of off-budgetary expenditures, for example. As a direct policy implication, it is relevant to reinvigorate budget transparency debates for the management of EI revenues, to ensure that citizens, parliaments and independent audit institutions are able to monitor and oversee the transparent execution of these resources.

\subsection{Federalism and extractive revenues}

This article finds no evidence of a direct relationship between the formal organisation of the territory (into a federal or unitary administration) and the magnitude of transfers to sub-national governments. The common expectation is that autonomous sub-national 
units in a federal state would have greater leverage to extract and manage taxation and non-tax revenues, compared to the more limited autonomy (or greater dependency) of subnational governments on the central government in a unitary state. The cases analysed suggest that a federal structure alone does not guarantee greater availability of EI revenues at the sub-national level. For example, there are federal cases like Mexico, which devolve a much lower percentage of EI revenues to local and state governments than unitary states like Bolivia and Peru.

a One potential explanation is that effective transfers of EI revenues take place when local governments increase their bargaining power vis-à-vis the central government, either through winning local elections, by organising social mobilisation or by making coalitions with the extractives sector. Some of these factors are present in the cases of Peru and Bolivia. In Colombia and Ecuador, governments were able to re-centralise the management of EI revenues given the weak and limited ability of sub-national governments to oppose the government or present an organised movement during the decade of reforms (Rudas Lleras and Espitia Zamora 2013).

b There also is considerable variation in the way EI revenues are distributed to local governments. Most but not all federal states tend to privilege allocations to state or regional governments (Brazil and Nigeria) whereas unitary states tend to benefit local or municipal governments. A potential explanation is that central governments in unitary states would prefer to target resources to municipal governments in order to enhance their political leverage over fragmented governments (as in the case of Indonesia and Peru), whereas in federal structures, central governments are less able to re-centralise EI revenues or influence the policy (and political) preferences of sub-national governments.

c Based on the available evidence, we cannot extract a direct association between the territorial organisation and the allocation of revenues, but we would make the case that federal states would be better equipped to manage the transfer of EI revenues to subnational governments in a more efficient and accountable manner (Ahmad and Mottu 2003).

\section{Conclusion}

The growing importance of the extractive sector in the developmental strategy of many poor and middle-income countries raises the question of the distribution of EI revenues among levels of government and across different jurisdictions at a given level. Theory provides clear guidance for designing such redistributive policies. Regarding vertical distribution, the theory says that each level of government should benefit from EI revenues in proportion to their functional responsibilities and that sub-national governments' finances should not rely on volatile revenue. Regarding horizontal distribution, technical criteria highlight the importance of compensating to the producing jurisdictions for the negative externalities linked to extraction without generating territorial unbalances or grievances due to an extremely unequal distribution of revenues. Our review of redistributive policies in ten resource-rich countries shows that institutional considerations are not sufficient to determine actual revenue sharing. The variety of criteria for the distribution of EI revenues points to political factors as the main drivers of those policies. In this article we have attempted a first cut at understanding what those political factors might be. The data do not show clear patterns. Neither the level of fiscal decentralisation nor the federal or unitary nature of the state seem to determine the proportion of EI revenues transferred to subnational governments. In contrast, the historical context in which EI-related transfers are negotiated and the relative strength of the subnational governments vis-à-vis the central government are the factors that seem to influence the level of EI-revenues transfers.

We find that the way in which the decentralised revenues are distributed between producing and non-producing territories also varies greatly in our sample countries. Here the level of fiscal decentralisation does seem to matter. Higher levels of fiscal decentralisation in the country are correlated with a more equal distribution across all the regions of the country. This suggests that differences in bargaining power of sub-national governments due to previous fiscal decentralisation might be the explanation. Decentralisation empowers all sub-national governments and decreases the asymmetry in negotiating power between non-producing regions and producing jurisdictions (that have 
the capacity to disrupt the activity of the extractive companies). Thus, the data presented in this article suggest that distributional policies are best explained by differences of bargaining power between the central and the sub-national governments and across sub-national jurisdictions. This conclusion calls for better understandings of the nature of such bargaining power in specific contexts - a task that we have

\section{Notes}

1 This mechanism is also known as 'derivation' according to Ehtisham Ahmad and Eric Mottu (2003) but we refer to 'devolution' in this article.

2 These territories are usually identified with those hosting infrastructure needed for the exploitation or transportation of minerals.

3 The data does not represent actual shares but EI revenue entitlements according to existing

\section{References}

Agustina, C.D.; Ahmad, E; Nugroho, D. and Siagian, H. (2012) Political Economy of Natural Resources Revenue Sharing in Indonesia, London: London School of Economics and Political Science

Ahmad, E. and Mottu, E. (2003) 'Oil Revenue Assignments: Country Experiences and Issues', in J. Davis, R. Ossowski and A. Fedelino (eds), Fiscal Policy Formulation and Implementation in Oil-producing Countries, Washington DC: International Monetary Fund Ahmad, E. and Singh, R. (2003) Political Economy of Oil-revenue Sharing in a Developing Country: Illustrations from Nigeria, Washington DC: International Monetary Fund

Arellano Yanguas, J. (2012) 'Mining and Conflict in Peru: Sowing the Minerals, Reaping a Hail of Stones', in Anthony Bebbington (ed.), Social Conflict, Economic Development and the Extractive Industry: Evidence from South America, London: Routledge

Arellano Yanguas, J. and Mejía Acosta, A. (2014) Extractive Industries, Revenue Allocation and Local Politics, Geneva: United Nations Research Institute for Social Development (UNRISD)

Banful, A.B. (2011) 'Do Formula-based Intergovernmental Transfer Mechanisms Eliminate Politically Motivated Targeting? Evidence from Ghana', Journal of Development Economics 9.2: 380-90

Bebbington, A. (2012) 'Extractive Industries, Socio-Environmental Conflicts and Political started in a separate paper (Arellano Yanguas and Mejía Acosta 2014). Despite well-developed theoretical rationale for sharing of revenues from extractive industries, how it is operationalised seems to rest ultimately on politics; thus the political relations between national and sub-national governments seem critical in shaping revenue policies.

legislation, and tends to underestimate the participation of central government. There are other types of EI revenues such as margins of profit from state-owned oil and mining companies that are managed by the national government and may be distributed to subnational governments in the form of discretional transfers.

Economic Transformations in Andean America', in Anthony Bebbington (ed.), Social Conflict, Economic Development and the Extractive Industry: Evidence from South America, London: Routledge Brosio, G. (2003) 'Oil Revenue and Fiscal Federalism', in J. Davis, R. Ossowski and A. Fedelino (eds), Fiscal Policy Formulation and Implementation in Oil-producing Countries, Washington DC: International Monetary Fund (IMF)

Crabtree, J. and Chaplin, A. (2013) Bolivia: Processes of Change, London: Zed Books

Davis, J.; Ossowski, R.; Daniel, J. and Barnett, S. (2003) 'Stabilization and Saving Funds for Non-renewable Resources: Experience and Fiscal Policy Implications', in J.M. Davis, R. Ossowski and A. Fedelino (eds), Fiscal Policy Formulation and Implementation in Oil-Producing Countries, Washington DC: International Monetary Fund (IMF)

Departamento Nacional Planeación-Colombia (2012) Sistema General de Regalías, Bogotá: Departamento Nacional de Planeación (DNP)

Energy Sector Management Assistance Programme (2005) Comparative Study on the Distribution of Oil Rents in Bolivia, Colombia, Ecuador, and Peru, Washington DC: UNDP/World Bank

Falleti, T. (2010) Decentralization and Subnational Politics in Latin America, Cambridge: Cambridge University Press

Fick, J. (2013) 'Brazil's Supreme Court Suspends New Oil-Royalties Regime', The Wall Street Journal,www.rigzone.com/news/oil_gas/a/ 
125151/Brazils_Supreme_Court_Suspends_New OilRoyalties_Regime (accessed 6 July 2014)

Iledare, W. and Suberu, R. (2012) 'Nigeria', in

George Anderson (ed.), Oil and Gas in Federal

Systems, Ontario: Oxford University Press

Canada

Kâ Diongue, A.; Giraud, G. and Renouard, C. (2011) Measuring the Contribution of Extractive Industries to Local Development: The Case of Oil Companies in Nigeria, Cergy-Pontoise: ESSEC Business School

Morgandi, M. (2008) Extractive Industries Revenues Distribution at the Sub-National Level: The Experience in Seven Resource-Rich Countries, New York: Revenue Watch Institute

Reuters (2013) Brazil President Signs Oil Royalty Law, Legal Challenge Expected, www.reuters.com/ article/2013/03/15/brazil-oil-royalties-idUSL 1N0C70C820130315 (accessed 6 July 2014)

Ross, M. (2007) 'How Can Mineral Rich States Reduce Inequality?', in Jeffrey Sachs, Joseph
E. Stiglitz and Macartan Humphreys (eds), Escaping the Resource Curse, New York: Columbia University Press

Rudas Lleras, G. and Espitia Zamora, J.E. (2013) 'Participación del Estado y la Sociedad en la Renta Minera', in Luis Jorge Garay Salamanca (ed.), Minería en Colombia: Fundamentos Para Superar el Modelo Extractivista, Bogota: Contraloría General de la República Ruiz Duran, G. (2011) Financiación y Fiscalidad Locales en América Latina, Barcelona: Programa URB-ALIII

Schoeder, L. and Smoke, P. (2002)

'Intergovernmental Transfers in Developing Countries: Concepts, International Practices and Policy Issues', in Paul Smoke and YunHwan Kim (eds), Intergovernmental Transfers in Asia: Currrent Practice and Challenges for the Future, Manila: Asian Development Bank 


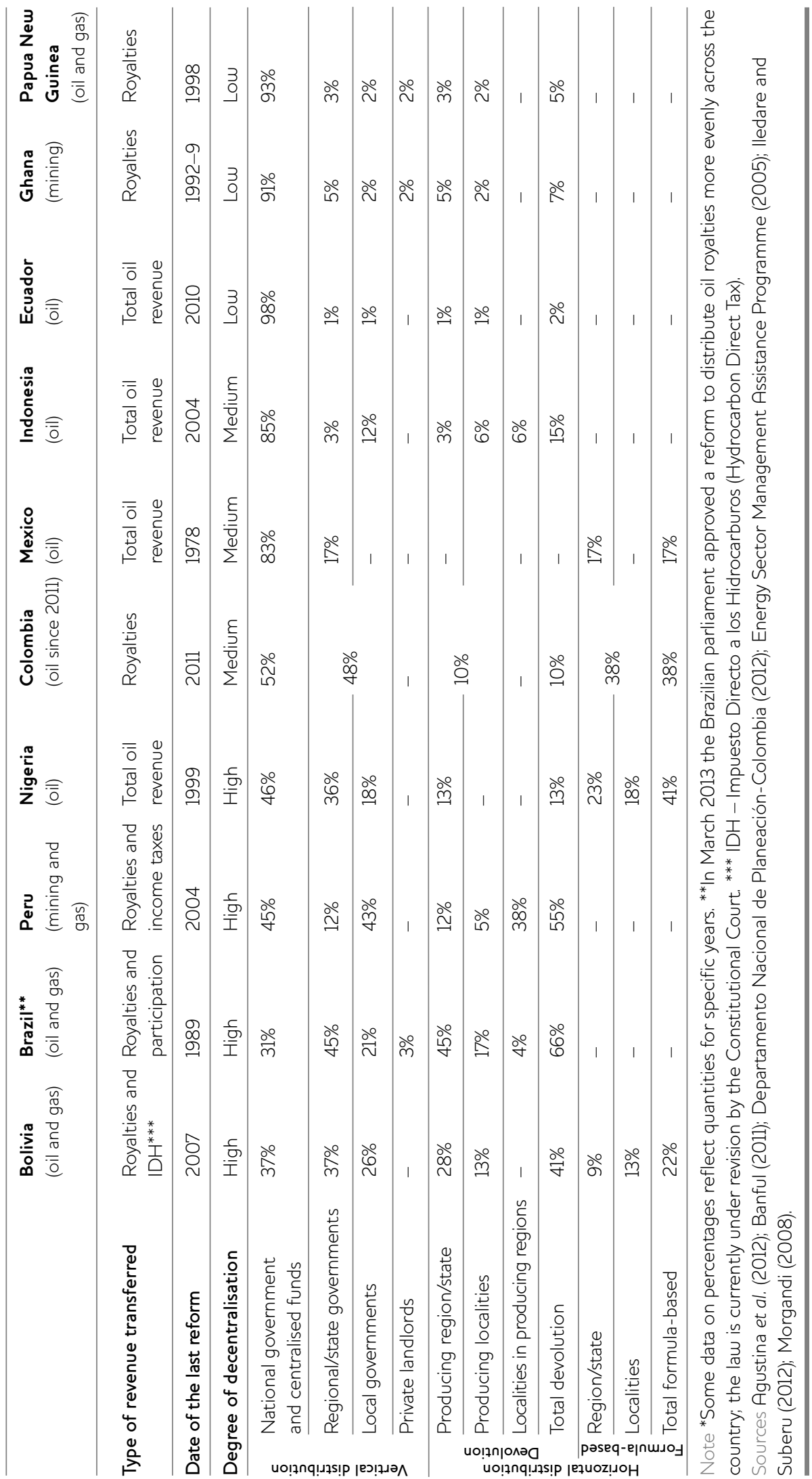

